\title{
Factors Affecting the Satisfaction of School Teachers with Performance Appraisal
}

\author{
System in Punjab \\ * Dr. Seema Arif, Associate Professor \\ ** Muhammad Nadeem, Principal Officer (Corresponding Author) \\ *** Dr. Fazli Khaliq, Lecturer
}

\begin{abstract}
Performance Appraisal System (PAS) is the tool the education department of Pakistan uses to evaluate the performance of teachers. Survey research was conducted to determine the satisfaction level of public-school teachers with conduction and outcomes of PAS. The correlational research design was planned to determine the perceptions of the teachers about their competencies in areas evaluated by PAS and its outcomes. A multistage random sampling technique was used to access the target sample of 900 higher secondary school teachers from 12 out of 36 districts of Punjab. Since it was a pioneer study, a self-constructed questionnaire was used for the survey piloted on two out of 12 selected districts. The questionnaire was distributed among 1200 teachers; 960 were retrieved, and 900 were tabulated and recorded on SPSS 21 for the final analysis. Both descriptive and inferential statistics were applied. After ensuring reliability, the items were factorized using the exploratory factor analysis technique yielding six factors. Pearson Correlation was conducted to determine the strength of the relationship among the variables, while multiple linear regressions using the stepwise method were conducted to get informed with the critical risk factors associated with the satisfaction of teachers with the conduction of PAS. The results reveal a highly complex situation faced by school teachers; though teachers have displayed complete knowledge about the conduction of the PAS process and its consequences, yet, not only the teachers seem deficient in the needed skills; they also lack motivation for self-development.
\end{abstract}

Keywords: Correlational Research, Performance Appraisal System, Secondary School Teachers, Satisfaction

\section{Introduction}

Each formal educational institution needs individuals to work conscientiously and appropriately for the smooth functioning of the institute (Nikijuluw, 2017). Performance Appraisal System (PAS) is a more strategic approach for integrating Human Resource (HR) activities, and it is used for evaluating the performance of teachers (Basak \& Govender, 2015) in Pakistan, changed from the Annual Confidential Report (ACR) to the Performance Evaluation Report (PER) in 2013 (Ikramullah \& Zaman, 2013). It has been quite a time, yet, the stakeholders, that is, the teachers and the administrators have not been able to adapt to the new system.

PAS sets targets for employees according to job standards. PAS measures the teachers' actual performance relative to set standards and provides feedback for improvement. Teacher evaluation framework in higher secondary schools and its feedback played a vital role in developing the whole education system (OECD, 2013). Performance appraisal is practiced regularly in both public and private higher secondary schools of Pakistan with different objectives and operational differences.

The existing block of information does not fully cover the effectiveness of PAS. There is little previous research available that can be used to measure the evaluation system of higher secondary school teachers. We need to know how the principals and teachers understand it. Principals' and teachers' knowledge are limited to 'know-how' but not 'why' and 'how.' Therefore, we must measure

\footnotetext{
* University of Management and Technology Lahore. Email: seema.arif@umt.edu.pk

** Mines and Minerals Department Mianwali. Email: mnadeem439@gmail.com

*** National College of Physical Education Mardan Email: khaliq78@yahoo.com
} 
the satisfaction level of teachers about PAS as it is affecting the key actor in the education system of Pakistan.

In the view of Aguinis, Gottfredson, and Joo (2013), the employees demand better compensation, promotion, and communication with management. It is further stated that professional development needs training for improvement in the quality of work (Guest, 2017). However, performance standards could be improved in the same vein to ensure the overall effectiveness of the evaluation system. The goal of modern performance evaluation is not to punish but reinforce employees to learn and create a quality improvement culture. This objective is the most fulfilling for the goals of quality education in Pakistan, yet recent research (Nadeem, Arif \& Asghar, 2019; Nadeem, Arif \& Naeem, 2020) highlights that change of performance appraisal system has not worked wonders in 7 years for the school education system in Punjab.

In this study, the researchers have highlighted the skills which are evaluated by PAS, such as class management, quality teaching, punctuality, teamwork, motivation that founds the basis of teacher evaluation (Ali, Dahie, \& Ali, 2016). Mere measurement of teacher competency is never enough unless linked with the satisfaction of the process of measurement and desired consequences. The main objective of this research is: how teachers link their evaluation with mastery goals of selfimprovement and ultimate satisfaction of sailing through sustainable career success. PAS is a comprehensive process in which the performance of teachers is mentioned, measured, and improved. Several discrepancies have been found in the conduction of PAS in public higher secondary schools. It is observed that mostly performance evaluation is conducted on teachers whose promotion is due; hence, the process has lost its objective quality, continuously demoralizing the schoolteachers (Nadeem et al., 2019). This attitude has undermined the credibility of the appraisal system; hence a comprehensive study was planned to fill the gap. This study will inform educationists and policymakers of the needs of key stakeholders, teachers, so that they can modify and improve PAS accordingly.

\section{Statement of the Problem}

The present study is conducted to measure interrelationship among teacher competencies (classroom management and teamwork \& collaboration), awareness of the PAS as an evaluation system, and its outcomes, self-motivation, and satisfaction.

\section{Objectives}

1. To measure relationship between teacher competencies and teachers' satisfaction with PAS

2. To measures the relationship between the outcomes of PAS and teachers' satisfaction with PAS

3. To explore teacher competencies, awareness, and outcomes of PAS interact with teachers' satisfaction with PAS

\section{Research Questions}

1. What is the relationship between teacher competencies and teachers' satisfaction with PAS?

2. What is the relationship between the outcomes of PAS and teachers' satisfaction with PAS?

3. How teacher competencies, awareness, and outcomes of PAS interact with teachers' satisfaction with PAS?

\section{Literature Review}

PAS is perceived as a facilitator and motivator across the world; it is considered a successful regimen, to enhance employee performance (DeNisi \& Gonzalez, 2017). Educational sectors all over the world and the private education sector in Pakistan have been successful in obtaining desired results in teacher performance through its implementation (Ballou \& Springer, 2015; Ali et al., 2016).

In the context of schools, the aim is to provide quality instruction to pupils enabling them for complex problem solving of the twenty-first-century world. By analyzing the competence level of teachers, the schools can find discrepancies between the expected and actual performance of teachers that allows them to modify their policies and criteria to reach their goals (Skaalvik \& Skaalvik, 2017). The Appraisal system entails the purpose of empowering the school administration to get more control through continuous supervision and evaluation; some would attribute it as 'harassing,' 'bullying,' or even 'policing' the teachers (Arif, 2018; Martin, Fisher-Ari \& Kavanagh, 2020). 
Neoliberal policies for school reform are counted as oppressive transforming teachers' identity and lived experience as more stressful, causing social anxiety and aloofness; these are some of the transgressions that teachers feel have infiltrated in their sacred profession (Fisher-Ari, Kavanagh, \& Martin, 2017). Firestone (2014) already warned that such teacher evaluation policies would be counterproductive as this conflict with motivation theories.

\section{Conceptual Framework}

This study has derived its conceptual framework from the expectancy theory of performance and teacher appraisal model (Decenzo \& Robbins 2007). Using this theory, researchers expect to find out what guides higher secondary school teachers' behavior; how they choose their daily actions being mindful of their effect on PAS. It is assumed that awareness of a process directs the choice of appropriate actions impacting not only teachers' performance but a teacher's satisfaction and commitment with the process as well (Finnigan, 2010; Suciu, Morten, \& LAZĂR, 2013;). The following figure demonstrates the diagrammatic representation of the interrelationship between the variables of the study.

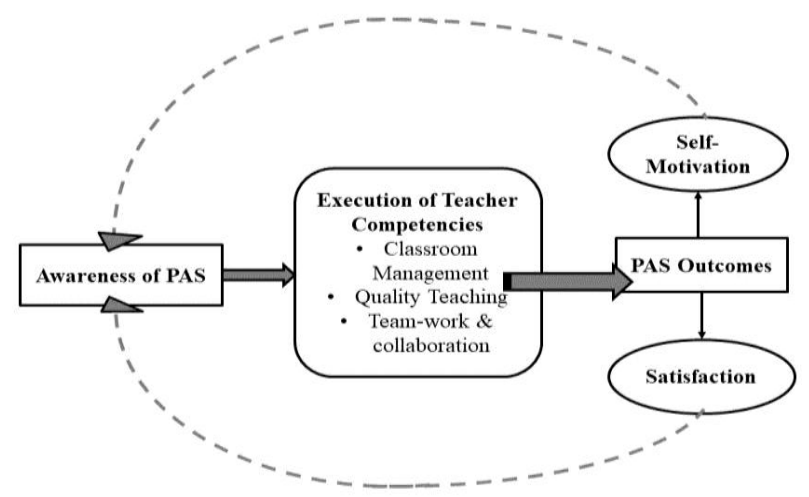

Fig.1 Performance Appraisal System and Teachers' Satisfaction

Teacher performance has been defined as an effort that is based on results obtained by teachers while fulfilling their job requirements (Tong \& Arvey, 2015). In contrast, performance is closely related to teacher work, which refers to the composite of knowledge, related practices, emerging relationships, and ethical considerations that encompass the role of a teacher (Liu \& Onwuegbuzie, 2014). Nowadays, the teacher work further reflects how teachers' work is being modified by overwhelming economic, political, and cultural events, and Pakistan is no exception.

PAS: The performance appraisal system was developed for schoolteachers according to the guideline of Pakistan Education Policy 2009; according to this, teachers' daily activities are judged against preset criteria and standards developed for the purpose. The reports thus generated can be used either for formative evaluation, to identify training needs for professional development, or may involve highstake decisions, such as a promotion or other incentives (Khan, Khan, Hussain, \& Shaheen, 2017). Both objectives hold teachers accountable for every action they take in schools.

Awareness with the PAS: In the context of teachers' performance appraisal, the management and the head of the school is required to guide teachers about the basics of PAS and its implementation process (Bachri Thalib, Arif, \& Ahmad, 2014). The policies, duration, criteria, and other aspects need elaboration for every teacher to be well informed during the implementation of PAS (Firestone, 2014). Thus, it is ensured that teachers are known to judge their performance and get clear what is expected of them throughout the year. It is further assumed that such awareness will allow teachers to maintain their teaching quality up to the mark.

Classroom Management: According to Kwok (2017), classroom management skills hold a significant position in teacher appraisal. In some of the countries such as Turkey and Bulgaria, it is the prime criterion for the evaluation of schoolteachers (Akin, Yildirim, \& Goodwin, 2016). Classroom management includes the skills for keeping students disciplined so that they behave appropriately. Teaching adolescents is a tough challenge, and a poorly managed classroom would leave a harmful effect on pupils (Flower, McKenna, \& Haring, 2017). Instead of enforcing punitive disciplines, teachers are expected to guide and counsel students toward self-management and self-regulated learning so that a classroom environment conducive to teaching and learning is maintained (Triplett, 2014). 
Quality of Teaching: According to Chamundeswari (2013), performance appraisal entails the identification of teaching quality, implying that teachers and their quality teaching play a key role in enhancing student achievement. Thus, it is a prime objective of every school and education system. Quality means standardization, following policies and rules, on the one hand, and continuously striving for self-improvement on the other (Fullan, 2014; Zepeda, 2017; Brandon, Hollweck, \& Whalen, 2018). Without practicing punctuality, discipline, self-reflection, and motivation, it remains a farfetched dream (Nadeem et al., 2019, 2020).

Motivation: A product of the performance appraisal action is the motivation (Kroll \& Moynihan, 2015; Ceschi, Dorofeeva \& Sartori, 2014). When performance is evaluated and teachers who stand out as extraordinary receive reward, it increases their motivation. This statement has been proved correct in the light of the reinforcement theory stating that an action has the potential to be repeated if it is reinforced (Elias, 2016). Therefore, performance appraisal is tied with both kinds of incentives: reward and punishment. It is futile to believe that only rewards reinforce the desired behaviors; fear of failure and resulting disgrace is a more powerful incentive (Suciu et al., 2013). Moreover, expectancy theory explicates that to earn every reward; one has to put an effort; therefore, the reward should be convincing, so should be the belief in the personal effort that 'I can do it.' In the absence of either of the two, motivation becomes weaker (Finnigan, 2010).

Teamwork and Collaboration: Teacher evaluation not only entails how a teacher has performed individually, but it is more concerned about how the teacher has interacted and collaborated within a team (Ceschi et al., 2014). Teamwork is essential for teachers as they collectively teach the students, and if they do not coordinate well enough, students will not receive a coherent education. Teamwork also involves building professional learning communities (Gillani, 2020).

\section{Satisfaction with PAS:}

A review of the literature suggests that PAS would be more effective if teachers are satisfied with its conduction and consequences. It is a common notion if teachers are appraised and rewarded on their excellent performance, it will encourage and motivate them to continue with their effective teaching (Chetty \& Rockoff, 2014). However, being a developing country, Pakistan cannot spend much on monetary incentives for teachers. Therefore, not only is it critical to investigate teachers' aspirations for their progress, empirical research must be carried out to determine teachers' perceptions about the needed skills for a sustainable career in the education system.

\section{Research Methodology}

The Researcher used the survey method to collect the data and answer the questions (Creswell, 2013). According to Fricker (2016) survey method helps to explain a wide variety of data from different respondents. Furthermore, it is assumed that data gathered during the research process serves as an objective measure of reality, as the research itself is independent of the Researcher. A self-constructed questionnaire was used to collect the data from higher secondary schools. However, the assistance of many senior teachers was sought in different districts for the timely collection of the data.

\section{Development of Research Instrument}

The questionnaire was self-constructed, suiting the purpose of the study. It has already been piloted (Nadeem et al., 2019) to enhance the validity and reliability of the process (Fricker, 2016). The questionnaire was divided into two parts. Part A collected demographic details of the research participants. Part B comprised of 44 items relevant to the factors of the study.

\section{Population and Sampling}

The population of the study comprised of teachers working in higher secondary schools of Punjab, which is a province in Pakistan. Stratified multistage random sampling was the technique used to approach the target sample. At the first stage, nine districts were chosen divided into the strata of high, average, and low performance, as shown in Table 1. In the second stage, ten schools were selected purposively, suiting the inclusion criterion of the most thickly populated school of the region. Ten schools were selected from each district with the right mix of gender and location. In the third and final stage, selected schools were rendered a cluster, and teachers working at the selected public higher secondary schools were approached for data collection. 
Table 1

Sample distribution of the study

\begin{tabular}{|c|c|c|c|c|}
\hline $\begin{array}{l}\text { Category } \\
\text { Population }\end{array}$ & $\begin{array}{l}\text { Higher Secondary Schools in } \\
\text { Punjab Districts }\end{array}$ & $\begin{array}{l}\text { Boys } \\
\text { Schools }\end{array}$ & $\begin{array}{l}\text { Girls' } \\
\text { Schools }\end{array}$ & Total Schools \\
\hline $\begin{array}{l}\text { Districts } \\
\text { High }\end{array}$ & $\begin{array}{l}\text { Selected Districts } \\
\text { Lahore }\end{array}$ & Sample & Sample & Sample \\
\hline Performance & Attock & 15 & 15 & 30 \\
\hline $\begin{array}{l}\text { Districts } \\
\text { Average }\end{array}$ & $\begin{array}{l}\text { Toba } \\
\text { Sahiwal }\end{array}$ & & & \\
\hline Performance & Okara & 15 & 15 & 30 \\
\hline Districts & Mianwali & & & \\
\hline Low & Bahawalpur & & & \\
\hline Performance & Vehari & 15 & 15 & 30 \\
\hline Districts & Jang & & & \\
\hline Total & 9 & 45 & 45 & 90 \\
\hline
\end{tabular}

The above table shows that the target sample comprised 900 teachers teaching at the higher secondary level.

\section{Data Collection}

Each school was visited 2-3 times. The initial visit was made for an introduction and getting a formal consent from the principal for data collection. A second visit was done to distribute questionnaires. One thousand two hundred questionnaires were distributed to teachers, out of which 960 returned; only 900 were complete, which were included for the final analysis.

The data was organized and recorded in Statistical Package for Social Science (SPSS) edition 21. Data screening was performed to find out missing values and abnormal values. Data normality and outliers, as well as homogeneity of the samples, were assessed to proceed with further analysis.

The demographic details of the data are given below in Table 2 .

Table 2

Demography

\begin{tabular}{lcc}
\hline Gender & $\mathrm{f}$ & $\%$ \\
\hline Male & 450 & 50.0 \\
Females & 450 & 50.0 \\
Total & 900 & 100.0 \\
\hline Age & & \\
\hline 30 below & 80 & 9.00 \\
$30-35$ & 136 & 15.00 \\
$35-40$ & 198 & 22.00 \\
$40-50$ & 310 & 34.00 \\
$50-60$ & 176 & 20.00 \\
Total & 900 & 100.00 \\
\hline Qualification & & \\
\hline Masters & 595 & 66.00 \\
MPhil & 266 & 30.00 \\
PhD & 39 & 4.00 \\
Total & 900 & 100.0 \\
\hline Experience & & \\
\hline $1-5$ & 310 & 34.00 \\
6-10 & 295 & 33.00 \\
$11-15$ & 133 & 15.00 \\
16 or more & 162 & 18.00 \\
Total & 900 & 100.0 \\
\hline Data Analysia & &
\end{tabular}

\section{Data Analysis}

First, the reliability of the questionnaire was checked; the calculated value of Cronbach alpha was 0.800 precisely. Exploratory factor analysis (EFA) analysis and the Scree plot affirmed the factorability of data into six factors with a value of 0.649 for Kaiser-Meyer-Olkin (KMO) measure of sampling adequacy, which should be more than 0.6; Bartlett's Test of Sphericity, with chi-square value of $\chi^{2}(46072.096, \mathrm{p}<.05)$. 


\section{Factor Analysis}

Principal Component Factoring (Exploratory method) with Varimax rotation and Kaiser Normalization, was used to confirm the extracted factors (Fabrigar, Wegener, MacCallum, \& Strahan, 1999). Most of the rotations converged in 3 iterations and converged in the six factors (Awareness, Classroom Management, Motivation, Teamwork \& Collaboration, PAS Outcomes \& Satisfaction with PAS), which were further used for the final analysis. All criteria suggested reasonable factorability; for instance, calculated alpha for the factors was 0.4 or more with at least one other item in the factor. See Appendix A for details

\section{Pearson's Product Moment Correlation}

Pearson Product Moment correlation test was applied to check the association between the factors of the study. A correlation matrix is simply a quadrilateral selection of numbers, which gives the correlation coefficients of each variable with every other variable under investigation (Klingenberg, 2009). The factors under study include awareness about PAS, classroom management, quality of teaching, motivation, teamwork, punctuality, satisfaction with PAS, management support, dissatisfaction with PAS, and need for improvement.

Table 3

Correlation Matrix displaying Relationships among the Variables of the study $(N=900)$

\begin{tabular}{|c|c|c|c|c|c|c|c|}
\hline & & 1 & 2 & 3 & 4 & 5 & 6 \\
\hline 1 & PAS Awareness & 1 & .056 & $-.315^{* * *}$ & $-.241^{* * *}$ & $-.176^{* * *}$ & $.704^{* *}$ \\
\hline 2 & $\begin{array}{l}\text { Classroom } \\
\text { Management }\end{array}$ & & 1 & $.374^{* *}$ & $.362^{* *}$ & $.595^{* *}$ & $.233^{* *}$ \\
\hline 3 & $\begin{array}{l}\text { Motivation for } \\
\text { Improvement }\end{array}$ & & & 1 & $.547^{* *}$ & $.285^{* *}$ & $-.214^{* *}$ \\
\hline 4 & $\begin{array}{l}\text { Teamwork \& } \\
\text { Collaboration }\end{array}$ & & & & 1 & $.531^{* *}$ & $-.084^{*}$ \\
\hline 5 & Positive Outcomes & & & & & 1 & .007 \\
\hline 6 & $\begin{array}{l}\text { Satisfaction with } \\
\text { PAS }\end{array}$ & & & & & & 1 \\
\hline
\end{tabular}

**. Correlation is significant at the 0.01 level (2-tailed).

*. Correlation is significant at the 0.05 level (2-tailed).

The strongest positive correlation exists between awareness of the PAS process and satisfaction with PAS ( $\mathrm{r}=.704 ; \mathrm{p}<.001)$. Weak to moderate negative correlation exists between awareness of PAS process and classroom management $(\mathrm{r}=-.315 ; \mathrm{p}<.001)$, awareness of PAS process and motivation for improvement $(\mathrm{r}=-.241 ; \mathrm{p}<.001)$, and awareness of PAS process and positive outcomes of PAS $(\mathrm{r}=-.176 ; \mathrm{p}<.001)$.

Classroom management has strong and positive relationship with positive outcomes $(\mathrm{r}=.595$; $\mathrm{p}<.001)$, moderate relationship with motivation for improvement $(\mathrm{r}=.374 ; \mathrm{p}<.001)$, and teamwork and collaboration $(\mathrm{r}=.362 ; \mathrm{p}<.001)$, and weak but positive relationship with satisfaction with PAS $(\mathrm{r}=.233 ; \mathrm{p}<.001)$. Similarly, teamwork and collaboration have a strong and positive relationship with positive outcomes $(\mathrm{r}=.547 ; \mathrm{p}<.001)$, and motivation for improvement $(\mathrm{r}=.531 ; \mathrm{p}<.001)$, but none of these translate into satisfaction with PAS.

\section{Multiple Linear Regression (The satisfaction of Teachers with the PAS Process is the dependent variable)}

Since all factors were found to be significantly correlated with each other, multiple linear regression using the Stepwise method was used to find the strong predictors of satisfaction with PAS; therefore, it was used to build a model by adding or removing predictor variables (Mundry \& Nunn, 2008). Awareness with the process of PAS, classroom management, motivation, teamwork, and collaboration were the independent variables used to check their prediction value of satisfaction with PAS. Four different models were generated, which are briefly discussed below.

Table 4

Stepwise Regression (Dependent Variable: Satisfaction with PAS)

\begin{tabular}{llccccc}
\hline & Model & $\beta$ value & $\mathrm{t}$ value & $\mathrm{p}$ value & Tolerance & VIF \\
\hline 1 & (Constant) & & 7.366 & .000 & & \\
& PAS Awareness & .704 & 29.691 & .000 & 1.000 & 1.000 \\
& (Constant) & & -3.357 & .001 & & \\
& PAS Awareness & .693 & 30.312 & .000 & .997 & 1.003
\end{tabular}




\begin{tabular}{|c|c|c|c|c|c|c|}
\hline \multirow{5}{*}{3} & Classroom Management & .194 & 8.470 & .000 & .997 & 1.003 \\
\hline & (Constant) & & -1.103 & .270 & & \\
\hline & PAS Awareness & .662 & 27.157 & .000 & .865 & 1.156 \\
\hline & Classroom Management & .229 & 9.193 & .000 & .827 & 1.210 \\
\hline & $\begin{array}{l}\text { Motivation for } \\
\text { Improvement }\end{array}$ & -.091 & -3.469 & .001 & .747 & 1.339 \\
\hline \multirow[t]{5}{*}{4} & (Constant) & & -1.847 & .065 & & \\
\hline & PAS Awareness & .670 & 27.292 & .000 & .850 & 1.176 \\
\hline & Classroom Management & .216 & 8.457 & .000 & .785 & 1.274 \\
\hline & $\begin{array}{l}\text { Motivation for } \\
\text { Improvement }\end{array}$ & -.119 & -4.131 & .000 & 616 & 1.623 \\
\hline & $\begin{array}{l}\text { Teamwork \& } \\
\text { Collaboration }\end{array}$ & .065 & 2.324 & .020 & 660 & 1.514 \\
\hline
\end{tabular}

Satisfaction with PAS was the dependent variable and awareness of the PAS process, classroom management, and motivation for improvement, PAS outcomes, teamwork, and collaboration were added as independent variables to compute predictability of these variables. The variable, PAS outcomes, was excluded, and four models were generated consequently: Model 1 describes that awareness of the PAS process is solely responsible for $70 \%$ variation in the dependent variable, satisfaction with PAS. Model 2 states that awareness of the PAS process and classroom management may collectively cause more than 79\% variation in satisfaction with PAS. Model 3 explicates that awareness of the PAS process, classroom management, and motivation for improvement together may cause more than $77 \%$ variation collectively in satisfaction with PAS. Model 4 unfolds ultimately that awareness of the PAS process, classroom management, motivation for improvement, and teamwork and collaboration may cause more than $94 \%$ variation collectively in the dependent variable, satisfaction with PAS.

\section{Conclusions}

Based on the findings, the strongest correlation existed between awareness about PAS and Satisfaction with PAS and classroom management and positive outcomes. Motivation and teamwork and collaboration are also strongly linked with each other. On the other hand, moderate to weak negative associations are also observed. Awareness was in a negative association with motivation for improvement, teamwork, and positive outcomes. Satisfaction is also negatively correlated with motivation for improvement and teamwork and collaboration. Similar results were displayed by regression analysis. These results paint an extremely negative picture of the awareness of PAS; it means that the management responsible for creating awareness has not been successful. According to expectancy theory, if people do not expect the desired outcomes, they do not expend the desired effort.

\section{Discussion}

In recent times, performance appraisal is pivotal for every organization. The study at hand was conducted to check the satisfaction level of teachers about the appraisal system. Karimi, Malik, and Hussain (2011) endorsed the relationships between the performance appraisal system and job satisfaction. The research concluded that the conduction of the appraisal system plays a crucial role in the employee's performance; however, the awareness about conduction holds critical importance. PAS awareness positively affects classroom management; similar results were shared by other researchers as well (Triplett, 2014; Arifin, 2015; Akin et al., 2017; Flower et al., 2017; Kwok, 2017).

Moreover, the article reported in a retrospective comparison that teachers' skills matter a lot for qualifying in teacher evaluation, especially, related to classroom management, teamwork, and keep oneself motivated for improvement. Liu \& Onwuegbuzie (2014) contended that it is difficult for teachers to remain updated in challenging times, and a gap is produced between their actual and expected skills; in such conditions, leadership should adopt facilitative management skills to equip teachers with the needed skills (Arif, Asghar, \& Mukhtar, 2020), so that the school teachers may assume new responsibilities of facing accountability challenge.

Argon (2015) explained that school principals must follow the rules and regulations during accountability adopt appropriate ways to conduct the appraisal. The goal of all evaluation is to increase student achievement; therefore, the higher authorities must regulate the efficacy of their actions. The developing countries, the demand for secondary education is ever-growing; therefore, schools are facing a teacher shortage of teachers, especially in rural areas (Ramzan, 2019). Moreover, 
responsibilities are ever-increasing on teachers for the inclusion of diverse students, maintaining discipline, retention, and dropout. It also supports that teachers' skills for classroom management contribute to the expected positive outcomes and consequent satisfaction with the appraisal system, teachers in classroom management, and quality of teaching.

Moreover, this study confirms the results of many other studies, such as Rawung (2013), who opined that motivation is indicative of teamwork and collaborative work resulting from appreciation of individual and group work. Motivation is also influenced to some degree by satisfaction with the appraisal system. Moreover, Bogler (2005) stated that teacher empowerment enhances self-efficacy and morale for better classroom management and quality teaching. Sato \& Rabinowitz (2010) related that the purpose of accountability in education systems was to claim responsibility for their actions while serving the purpose of improvement in teaching and learning. Motivation is the key to development, and to retain teacher morale, teachers' opinions must be included in the system carrying out teacher accountability (Steins et al., 2020).

\section{Implications}

Although research on the technical merits of teacher evaluation systems has been ongoing, fewer studies have examined the perceptions of practitioners regarding the appraisal system (Paufler \& Sloat, 2020); this study has contributed in this aspect reflecting not only how stakeholders felt, but also commenting on the overall effectiveness of the system. It is included that the overall effectiveness of the appraisal system is not impressive since it is not resulting in teacher motivation for self-improvement or satisfaction and commitment with the system. It is alarming since, for twothird of the world, the objective of teacher evaluation is the professional development of teachers (Khan et al., 2017). Hence to achieve better results, the improvement in the system is needed.

Teacher evaluation involves high-stakes accountability leading to promotion, demotion, or some punishment; the education department, with the implementation of the PEDA act, has not been able to eliminate fear from the hearts of teachers. The term 'accountability' and 'appraisal' are somewhat taboo, and nobody wants to speak about it frankly (BachriThalib et al., 2014; Arifin, 2015; Nadeem et al., 2020). Fear of failure is a killer of motivation and self-efficacy; therefore, fear of failure must be eliminated to reach objectives of quality teaching in Pakistani public schools (Firestone, 2014).

The researchers recommend that policymakers and implementers must be aware of these factors while conducting PAS; moreover, how the school principals and district administration is accountable for their behaviors during conduction, it is yet not clear. Therefore, feelings of suppression and oppression are clear from the results of this research, indicated by the negative correlation between teachers' motivation and satisfaction with PAS. Similar oppressed feelings of teachers have been observed in recent research by the author (Arif, 2018; Arif \& Iqbal, 2019). The collective results of these studies lead to a single point agenda that policymakers must reflect on the causes of failure in achieving the desired objectives of PAS (improvement in teacher motivation, student achievement); only then the schools' education department of Punjab would be able to realize national goals of quality education. The same is reiterated by Kardas (2019) that bureaucratic accountability is hazardous in the way of teachers' professional development and student improvement.

Higher secondary education is admitted as the cornerstone of educational systems in Pakistan as it leads to university higher education; therefore, the provision of quality education is in formidable here. However, higher secondary school teachers are struggling with a plethora of problems incurred by the advent of neoliberal policies infested with individual accountability. Researchers remark that these policies have caused an increase in teachers' vulnerability, attrition, and dissatisfaction (Argon, 2015; DeNisi \& Gonzalez, 2017; Fisher-Ari et al., 2017 ;). It is a huge challenge confronting the schools education department Punjab; moreover, it is recommended to them that appraisal (summative evaluation) must be linked with continuous supervision (formative evaluation) to get better results (Adam, Mombourquette, Brandon, Hunter, Friesen, Koh, et al., 2018); whereas the suggested management styles to conduct appraisal would be participative and delegative conforming to interpersonal leadership improving long-term relationships between the stakeholders (Arif et al., 2020). 


\section{References}

Aguinis, H., Gottfredson, R. K., \& Joo, H. (2013). Best-practice recommendations for defining, identifying, and handling outliers. Organizational Research Methods, 16(2), 270-301.

Akin, S., Yildirim, A., \& Goodwin, A. L. (2016). Classroom Management through the Eyes of Elementary Teachers in Turkey: A Phenomenological Study. Educational Sciences: Theory and Practice, 16(3), 771-797.

Ali, A. Y., Dahie, A. M., \& Ali, A. A. (2016). Teacher motivation and school performance, the mediating effect of job satisfaction: Survey from Secondary schools in Mogadishu. International Journal of Education and Social Science, 3(1), 24-38.

Argon, T. (2015). Teacher and administrator views on school principals' accountability. Educational Sciences: Theory \& Practice, 15(4), 925-944

Arif, S. (2018). Dark Side of Leadership in Educational Setting. In M. F. Brandebo and A. Alvinius (Eds.) Dark Sides of Organizational Behavior and Leadership (pp. 2-22). London, IntechOPen.

Arif, S. \& Iqbal, S. (2019). Male hegemony vs. women empowerment: case of schoolteachers. Paper presented in $2^{\text {nd }}$ International Interdisciplinary Conference on Gender, Work and Society (2728 April), Lahore University of Management Sciences (LUMS), Lahore, Pakistan.

Arif, S. Asghar, Z., \& Mukhtar, M. (2020). Interactive effect of school principals' leadership styles and teacher characteristics on curriculum implementation at public secondary schools of Punjab. UMT Education Review, 3(1), 95-119.

Arifin, H. M. (2015). The influence of competence, motivation, and organizational culture to high school teacher job satisfaction and performance. International Education Studies, 8(1), 38-45.

Bachri Thalib, S., Arif, M., \& Ahmad, M. A. (2014). The Influence of Certification toward Work Motivation, Job Satisfaction, and Performance of State High School S Guidance and Counseling Teacher in South Sulawesi. International Journal of Science and Technology Research, 3(8), 386-394.

Basak, S. K., \& Govender, D. W. (2015). Theoretical framework of the factors affecting university academics' job satisfaction. The International Business \& Economics Research Journal (Online), 14(2), 317

Ballou, D., \& Springer, M. G. (2015). Using student test scores to measure teacher performance: Some problems in the design and implementation of evaluation systems. Educational Researcher, 44(2), 77-86.

Bogler, R. (2005). Satisfaction of Jewish and Arab teachers in Israel. The Journal of Social Psychology, 1(145), 19-33

Brandon, J., Hollweck, T., Donlevy, J. K., \& Whalen, C. (2018). Teacher supervision and evaluation challenges: Canadian perspectives on overall instructional leadership. Teachers and Teaching, 24(3), 263-280.

Chamundeswari, S. 2. (2013). Job satisfaction and performance of schoolteachers. International Journal of Academic Research in Business and Social Sciences, 3(5), 420.

Ceschi, A., Dorofeeva, K., \& Sartori, R. (2014). Studying teamwork and team climate by using a business simulation: how communication and innovation can improve group learning and decision-making performance. European Journal of Training and Development, 38(3), 211230.

Chetty, R., Friedman, J. N., \& Rockoff, J. E. (2014). Measuring the impacts of teachers II: Teacher value-added and student outcomes in adulthood. American Economic Review, 104(9), 263379.

Creswell, J. (2013). Qualitative inquiry and research design: Five different approaches. Thousand Oaks: CA: SAGE.

DuneCenzo, D. A., \& Robbins, S. P. (2007). Supervision today. Upper Saddle River, NJ: Pearson

DeNisi, A. S., \& Gonzalez, J. A. (2017). Design performance appraisal systems to improve performance. In E, A. Locke (Ed). The Blackwell Handbook of Principles of Organizational Behavior, 63-75. NY: Wiley

Elias, A. A. (2016). Analyzing the stakes of stakeholders in research and development project management: a systems approach. Research and Development Management, 46(4), 749-760. 
Fabrigar, L. R., Wegener, D. T., MacCallum, R. C., \& Strahan, E. J. (1999). Evaluating the use of exploratory factor analysis in psychological research. Psychological Methods, 4(3), 272-291.

Finnigan, K. S. (2010) Principal leadership and teacher motivation under high-stakes accountability policies. Leadership and Policy in Schools, 9(2), 161-189.

Firestone, W. A. (2014). Teacher evaluation policy and conflicting theories of motivation. Educational Researcher, 43(2), 100-107.

Flower, A., McKenna, J. W., \& Haring, C. D. (2017). Behavior and classroom management: Are teacher preparation programs preparing our teachers? Preventing School Failure: Alternative Education for Children and Youth, 61(2), 163-169.

Fricker Jr, R. D. (2016). Sampling methods for online surveys. The SAGE handbook of online research methods, 162-183.

Fullan, M. (2014). The principal: Three keys to maximizing impact. San Francisco, CA: Jossey-Bass.

Gillani, M. (2020). The relationship between professional learning communities, teacher loyalty, and professional commitment. Dissertation (MPhil), University of Management and Technology, Lahore, Pakistan.

Guest, D. E. (2017). Human resource management and employee well-being: Towards anew analytic framework. Human Resource Management Journal, 27(1), 22-38.

Ikramullah, M., Shah, B., Khan, S., Hassan, F. S. U., \& Zaman, T. (2013). Purposes of performance appraisal system: A perceptual study of civil servants in District Dera Ismail Khan Pakistan. International journal of business and management, 7(3), 142.

Kardaş, D. P. (2019). Putting bureaucratic accountability into a perspective in terms of academic achievement. Educational Assessment, Evaluation, and Accountability, 31(3), 349-375.

Karimi, R., Malik, M. I., \& Hussain, S. (2011). Examining the Relationship of Performance Appraisal System and Employee Satisfaction. International Journal of Business and Social Science, 2(22), 243-247.

Khan, G., Khan, A., Hussain, S., \& Shaheen, N. (2017). Teacher Evaluation: Global Perspectives and Lessons for Pakistan. Dialogue (Pakistan), 12(3).

Klingenberg, C. P. (2009). Morphometric integration and modularity in configurations of landmarks: tools for evaluating a priori hypotheses. Evolution \& Development, 11(4), 405-421.

Kroll, A., \& Moynihan, D. P. (2015). Does training matter? Evidence from performance management reforms. Public Administration Review, 75(3), 411-420.

Kwok, A. (2017). Relationships between instructional quality and classroom management for beginning urban teachers. Educational Researcher, 46(7), 355-365.

Liu, S., \& Onwuegbuzie, A. J. (2014). Teachers' motivation for entering the teaching profession and their job satisfaction: A cross-cultural comparison of China and other countries. Learning Environments Research, 17(1), 75-94.

Martin, A. E., Fisher-Ari, T.R., \& Kavanagh, K. M. (2020). Our schools turned into literal police states. disciplinary power and novice teachers enduring a cheating scandal, educational studies, 56(3), 306-329.

Mundry, R., \& Nunn, C. L. (2008). Stepwise model fitting and statistical inference: turning noise into signal pollution. The American Naturalist, 173(1), 119-123.

Nikijuluw, R. P. J. V. (2017). A review of the literature of quality and performance management. JURNAL MANEKSI, 6(1), 1-6.

Nadeem, M., Arif, S. \& Asghar, Z. (2019). Effectiveness of the teacher appraisal system in public higher secondary schools of Punjab (Pakistan). Global Regional Review, 4(1), 194- 208.

Nadeem, M., Arif, S., \& Naeem, M. (2020). The Role of Principals and Administrators in Performance Appraisal of School Teachers in Punjab. Sir-Syed Journal of Education and Social Sciences, 3(2), 132-142.

OECD (2013). Teachers for the 21st century: Using evaluation to improve teaching. OECD Publishing.

Paufler, N. A., \& Sloat, E. F. (2020). Using standards to evaluate accountability policy in context: School administrator and teacher perceptions of a teacher evaluation system. Studies in Educational Evaluation, 64, 100806. 
Ramzan, M. (2019). Teacher shortage at secondary level in the rural areas of district Narowal. Dissertation (MPhil), University of Management and Technology, Lahore, Pakistan

Rawung, F. H. (2013). The effect of leadership on the work motivation of higher education administration employees (Study at Manado State University). Journal of Business and Management, 15(1), 28-33.

Sato, E., \& Rabinowitz, S.N. (2010). Evaluation and accountability. In P. Peterson, E. Baker \& B. McGaw (Eds.), International encyclopedia of education (3rd ed., pp. 600- 606), Oxford, England: Elsevier.

Steins, G., Behravan, B., \& Behnke, K. (2020). Is resistance futile? Teachers' viewpoints about school inspection-Taking practitioners' perspectives into account. Studies in Educational Evaluation, 64, 100825.

Suciu, L. E., Mortan, M., \& LAZĂR, L. (2013). Vroom's expectancy theory. An empirical study: Civil servant's performance appraisal influencing expectancy. Transylvanian Review of Administrative Sciences, 9(39), 180-200

Skaalvik, E. M., \& Skaalvik, S. (2017). Motivated for teaching? Associations with school goal structure, teacher self-efficacy, job satisfaction, and emotional exhaustion. Teaching and Teacher Education, 67, 152-160.

Tong, Y. K. \& Arvey, R. D. (2015). Managing complexity via the competing values framework. Journal of Management Development, 34(6), 653-673.

Triplett, K. (2014). Order in the Courtroom...I Mean Order in the Classroom. The Field Experience Journal, 14(2), 38-48. Zepeda, S.J. (2017). Instructional supervision: Applying tools \& concepts $\left(4^{\text {th }}\right.$ Ed.). NY: Routledge.

Zepeda, S.J. (2017). Instructional supervision: Applying tools and Concepts ( $4^{\text {th }}$ Ed.). NY: Routledge. 